\title{
ČETRTA KONFERENCA 0 IZOBRAŽEVANJU IN UČENJU STAREJŠIH
}

P

ravijo, da je Univerza v Ulmu »najvišja nemška univerza«. Najvišja zato, ker stoji zunaj mesta na vzpetini. Res je, da slovi po svojih tehniških fakultetah, pa vendar v Ulmu niso pozabili na družbene vede. Znanja iz teh ved si je na Univerzi v Ulmu moč pridobiti pri ZAWIW, Univerzitetnem centru za splošno nadaljevalno izobraževanje. Pri tem centru pa je leta 1994 nastal tudi sedež Evropske zveze "Učenje v poznejših letih «. Tako je v njenem okviru lani potekala v Ulmu že četrta konferenca, posvečena izobraževanju in učenju starejših odraslih.

\section{UČENJE IN IZOBRAŽEVANJE ZA VSE}

Na konferenci so se odprla mnoga vprašanja $\mathrm{v}$ zvezi z demokratizacijo učenja in izobraževanja. Vse bolj je videti, da se zdaj vloga učitelja zares spreminja, in tisti, ki tega ne zaznajo, bodo najverjetneje doživeli presenečenja. Predavatelji, ki bodo svoja predavanja zapisali, jih zvočno in slikovno opremili ter jih objavili na internetu, bodo postali odveč, če ne bodo opravljali še neke druge, povsem drugačne vloge; vloge svetovalca, ki mladega človeka vodi skozi razmišljanje, ga opozarja na cilje, ki naj jih doseže, mu daje psihološko podporo.

Obstoju univerz v podobi, ki smo je bili vajeni doslej, grozijo tudi tako imenovane »industrijske univerze «, ki jih ustanavlja industrija. Če pozorneje razmišljamo o vzrokih, zakaj prihaja do vzporednega sistema univerz, ugotovimo, da se univerza ne uspe dovolj hitro odzvati na nove potrebe in izzive, velika industrija pa želi znanja, ki jih potrebuje. Po drugi strani pa je res tudi to, da so se potrebe po znanju občutno razmahnile, in tako je v izobraževalnem sektorju moč ustvariti tudi veliko dohodka. Tedaj ni nenavadno, da se indu- strija in kapital zanimata za ustanavljanje univerz. Tako se morajo univerze nemudoma odpreti številnim možnostim, ki jih ponuja nova tehnologija učenja. Le tako bo njihov program ostal zanimiv. Pa ne le univerze, marveč tudi univerze za tretje življenjsko obdobje.

\section{INTERNET JE SREDSTVO ZA VSE GENERACIJE}

Tema konference je bila pomembna tudi zato, ker učinkovito razbija stereotipne poglede na učenje in zmožnosti starejših, tako $\mathrm{v}$ javnosti kot pri starejših samih. Uporabo interneta, še posebej tisto interaktivno, starejši povezujejo z mladimi. Po drugi strani tudi mladi sami verjamejo, da so nove tehnologije njihova domena.

"Moji vnuki so dejali, da bo zdaj treba starejše vpeljati v elektronsko dobo, « je dejal upokojeni prof. Tom Holloway iz Velike Britanije ... No, in to misel so namenili meni, ki sem svojo prvo elektronsko pošto poslal že leta 1973, ko sem bil na čelu nekega oddelka pri IBM-u. «

Prof. Holloway je tako osvetlil morda največjo težavo v učenju starejših: nepreverjene resnice in predsodke, ki se naložijo starejšemu človeku.

Tom Holloway je predstavil The Third Age Trust in Seznam razgovorov. ${ }^{1} \mathrm{Na}$ tej mreži starejši opisujejo svoje vsakodnevno življenje, življenje danes in nekoč in odgovarjajo na vprašanja. Eno teh je bilo: »Kaj se dogaja vojnim žrtvam?" ali pa: "Kako običajni ljudje doživljajo politične in druge dogodke?"Znenada, skozi zgodbe, ki prihajajo iz mnogih držav, skozi dnevniške zapiske, fotografije, družinske arhive, pisma, ki so jih pisali stari očetje, ki jih starejši pošiljajo s pomočjo interneta, pa tudi ob glasbi takratnih šansonov, zaži- 


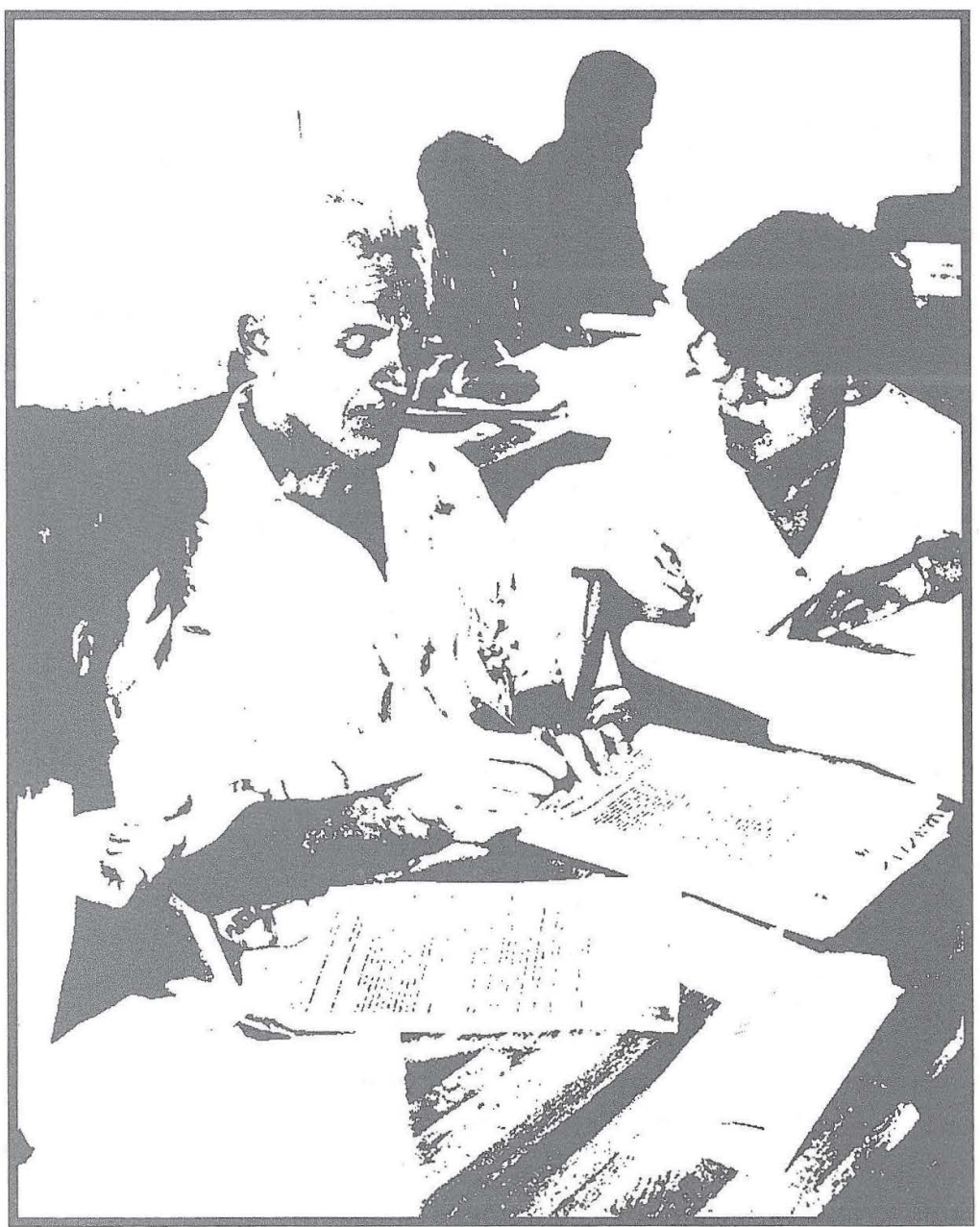

vi neki čas, ki je v uradnih zgodovinskih študijah povsem drugačen. Ena uspešnih tem so tudi prehranske navade nekoč in danes. Starejši tako mladim, ki najpogosteje zaidejo v naglo prehranjevanje, ki največkrat jedo in pijejo kar medtem, ko hodijo, odprejo pot v neki drug svet, v katerem je bila hrana družbeni obred, izraz kulture nekega okolja ali nekega družbenega sloja. Nasploh pa so družbeni in zasebni obredi tisto, kar mlade zanima.V njih se skriva podoba nekega drugačnega življenja, nekih drugih vrednot. $\mathrm{S}$ pomočjo prispevkov

\section{Starejši postajajo use pomembnejši vir učenja mladih.} na internetu nastaja tudi podoba druge plati vojne in $\mathrm{z}$ njo podlaga za učbenik zgodovine za mlade ljudi. V življenju starejših so bili tudi drugi veliki dogodki, kot so konec vojne, prihod prvega človeka na Luno itn. Pomembno je ugotoviti vezi, ki jih imajo starejši s svojo lastno zgodovino. $\mathrm{Ob}$ tem pa se odpira tudi vprašanje metod in načinov načrtnega prenašanja znanja starejših na mlade.

To prenašalsko vlogo je doslej zmeraj oprav- ljala šola. Na prihodnje rodove je prenesla vedenja o kulturnih dosežkih predhodnikov. Pri tem pa je šlo zmeraj za pretehtan izbor takšnih vedenj. Tokrat izbora ni, mladi pa morajo dovolj zgodaj razviti kritični duh, morajo si ustvariti lastna mnenja ob srečanju z gradivi, ki so jim na razpolago na internetu.

\section{PROJEKTI STAREJŠIH}

Prednost konference je bila $\mathrm{v}$ nadrobni predstavitvi projektov, ki so jih v evropskih državah že uresničili.

- Na konferenci so tako predstavili mreže LILL za učenje in sporazumevanje starejših pri Univerzi v Ulmu. ${ }^{2} \mathrm{~V}$ tej mreži zbirajo podatke o tem, kaj danes pomeni biti star v posameznih evropskih državah, pa tudi o tem, kaj so resnični problemi starosti in staranja, kakšne politične rešitve iskati. Starejši postajajo tako številni, da ne bo dovolj njihova vprašanja obravnavati zgolj v letu starejših. Ta vprašanja nezadržno silijo $\mathrm{v}$ ospredje družbenega razmišljanja.

- Nemci so ustvarili povezavo med radiom, televizijo in internetom. Nastala je oddaja "Priče zgodovine«. Nabirajo se spomini na politične dogodke, modo, preživljanje prostega časa, prehranjevanje itn. Ob njih pa starejši pošiljajo tudi pisma, fotografije s podstresij. Nekatere oddaje obravnavajo vizije in utopične poglede starejših o tisočletju pred nami. Kakšno družbo graditi, kaj spremeniti ... kaj ukiniti.

- Challenge to Global Citizenship je mreža, ki je nastala na Finskem. ${ }^{3}$ Vanjo se lahko vključijo vsi rodovi in ljudje vseh poklicev. Z navodili nas avtorji vodijo po raziskovalnem projektu s temami, ki zanimajo svet, s temami, ki naj pritegnejo dejavne državljane tega planeta. Pridobiti si je moč tudi maturo iz dejavnega državljanstva. $Z$ vključitvijo $\mathrm{v}$ ta in druge projekte na internetu starejši razvijajo svoje učne strategije. Pogosto morajo pred tem opraviti še eno pomembno delo, namreč ločiti se morajo od tistih učnih poti, ki so jih največkrat uspešno uporabljali v življenju.

$\mathrm{Na}$ Finskem je razkorak med generacijami vse večji. Tako so npr. finske družine zvečine jedrne in stari starši so pogosto $\mathrm{v}$ oddaljenih domovih za starejše. Prikazi iz teh domov, ki jih objavljajo mladi študenti po internetu, vzbudi- 
jo v otrocih željo, da bi zvedeli kaj več o svojih starih starših in o tem, kje in kako živijo.

- Finske univerze za tretje življenjsko obdobje starejše vključujejo v različne dejavnosti. Predavanja, projekti, raziskovanje, izdajanje publikacij. Posebej se te univerze ukvarjajo z razvojem usposobljenosti starejših za raziskovanje, vključujejo se $\mathrm{v}$ javne razprave o starosti in staranju in $\mathrm{v}$ iskanje zakonskih rešitev na tem področju, preučujejo zmožnosti starejših ljudi, tiste, ki se v starosti obnovijo ali ustvarijo na novo ter lahko služijo družbenemu razvoju. Posvečajo se razvoju učnih metod pri izobraževanju starejših.

Mnogi starejši ustanavljajo nevladne organizacije, v katerih izobražujejo drug drugega. Tako pride do izraza njihovo strokovno znanje. To se največkrat nateče $v$ študijska gradiva, ki se objavijo po internetu.

- V Franciji se je število univerz za tretje življenjsko obdobje ustalilo približno pri števil-

Finci ne želijo, da bi jih obravnavali kot stare, pa čeprav je starih nad 65 let kar 703 000. Tega ne želijo, kajti biti star pomeni zdrsniti po družbeni lestvici navzdol, saj so ugotovili, da pri njih zares spoštujejo stare le Romi, medtem ko jih finska družba obravnava predvsem kot pomembno kategorijo potrošnikov.

ki, ki so jo dosegli že takrat, ko je nastala prva v Toulousu. Univerza v Lyonu, ki zdaj deluje v središču mesta, pa tudi naokrog po vaseh, se povezuje z nemškimi univerzami, še posebej tistimi v vzhodnem delu te države.

- Na Nizozemskem se je leta 1993 razvila mreža Senior Web, ki spodbuja starejše, da se vključijo v družbo ${ }^{4}$. Internet tu služi kot povezava $\mathrm{z}$ lokalnim življenjem. Ponuja informacije, izobraževanje, budi interes starejših za dejavno prispevanje k skupnosti. Mreža ponuja izobraževanje za internetne inštruktorje. V to izobraževanje se je doslej vključilo veliko ljudi, starejših od 75 let. Nastarejši udeleženec šteje 98 let. Tudi on si je pridobil spričevalo inštruktorja. Izobraževanja te vrste tečejo v kraju, $\mathrm{v}$ kakšni knjižnici ali drugi ustanovi. Tudi v bankah, ki imajo za to primerno opremo. $\mathrm{Ob}$ njih se pomembno razvija "vrstniško so-učiteljevanje «, pri katerem gre, kot vemo, za medsebojno poučevanje.
- Jean Thompson iz Velike Britanije, ki vodi Univerzo za tretje življenjsko obdobje, eno tistih, ki ima izrazito razvite družbene razsežnosti, je povedala, kako deluje njihova mreža upokojenih prevajalcev. ${ }^{5}$ internet jim je pri tem $\mathrm{v}$ veliko pomoč. Jean nas je opozorila na to, kako natančno moramo preizkusiti spretnosti in znanja starejših, ki jih vključimo $\mathrm{v}$ kakšno dejavnost. Ti se velikokrat podcenijo ali pa so nji-
Najstarejši uporabnik interneta na Nizozemskem je star 98 let. hova znanja morda že zastarela ter jih je treba, preden pričnejo delati, osvežiti.

Univerza v Ulmu se je z IBM-om in neko banko dogovorila za sponzoriranje projekta Senior-Mobile Info. Gre za avtobus, ki potuje po deželi in animira starejšse za vključitev v interaktivno rabo interneta.

Ko smo na konferenci razmišljali, katera znanja so za starejše ključna, ali morda, katere usposobljenosti morajo doseči, smo spoznali, da je morda med vsemi usposobljenostmi obvladovanje tujih jezikov tisto, ki učno razvitim starejšim ljudem lahko najbolj odpre vrata $v$ druga izobraževanja in predvsem $v$ drugačno učenje s pomočjo nove tehnologije učenja.

Utrinke s poti je pripravila mag. Dušana Findeisen

${ }^{1}$ Seznam razgovorov je brezplačen. Pisati je treba Tomu Hollowayn (tom.holloway@u3a.org.uk) ali po faksu (+44) 192677 1707. Na tem seznamu je mogoče postavljati vprašanja in dobiti odgovore.

2 Naslov LILL $v$ kiberprostoru je: bttp://www.uniulm.de/LiLL

${ }^{3}$ Več informacij dobite na: The Finnish UN ASSOCIATION, UNIONINK.45 b, 00170 Helsinki,

Faks: +35891352173 ,

elektronska pošta: maailmankansalainen@ykliitto.fi

${ }^{4}$ Senior Web. NL., P. O. Box 222, 3500 AE Utrecht,

The Netherlands, telefon: (+31) 302769945 ,

Faks: (+31) 30271 3649),

elektronskapošta:info@seniorweb.nl

internet: bttp: /www.seniorweb.nl

${ }^{5}$ Jean Thompson,

elektronska pošta: jeant a easynet.co.uk 